\title{
ASO Author Reflections: Impact of Resection Volume on Risk of Local Recurrence-The OPBC-01/iTOP2 Study
}

\author{
Giacomo Montagna, MD, MPH${ }^{1}$, Walter P. Weber, $\mathrm{MD}^{2,3}$, Angelika Geroldinger, $\mathrm{PhD}^{4}$, and \\ Florian Fitzal, MD, MBA, FEBS ${ }^{5}$
}

${ }^{1}$ Breast Service, Department of Surgery, Memorial Sloan Kettering Cancer Center, New York, NY; ${ }^{2}$ Breast Center, University Hospital of Basel, Basel, Switzerland; ${ }^{3}$ University of Basel, Basel, Switzerland; ${ }^{4}$ Center for Medical Statistics, Informatics and Intelligent Systems, Medical University of Vienna, Vienna, Austria; ${ }^{5}$ Department of General Surgery and Breast Health Center, Medical University Vienna, Vienna, Austria

\section{PAST}

Oncoplastic breast conservation (OBC) techniques can be divided into low- to intermediate-volume (Clough level I, Tübingen 3,4) and large-volume (Clough level II, Tübingen 5,6) resections with removal of less or more than $20 \%$ of the breast tissue, respectively. ${ }^{1,2}$ The use of these techniques has become increasingly popular over the past 2 decades as they merge the curative intent of oncological surgery with plastic surgery techniques in an attempt to resect larger and/or multicentric tumors, reducing the necessity to perform mastectomies. ${ }^{3}$ However, most of the evidence evaluating the benefit of $\mathrm{OBC}$ is based on small single-center studies, limiting its applicability and generalizability. ${ }^{4}$ In this global retrospective study, we sought to determine whether OBC with large resection volumes improves local recurrence rates compared with conventional breast conservation or low-volume oncoplastic procedures in women with high-risk breast cancer.

\footnotetext{
ASO Author Reflections is a brief invited commentary on the article "Retrospective multicenter analysis comparing conventional with oncoplastic breast-conserving surgery: oncological and surgical outcomes in women with high-risk breast cancer from the OPBC-01/ iTOP2 study", Ann Surg Oncol. 2021
}

\section{(C) The Author(s) 2021}

First Received: 16 September 2021

Accepted: 16 September 2021;

Published Online: 28 September 2021

F. Fitzal, MD, MBA, FEBS

e-mail: florian.fitzal@meduniwien.ac.at

\section{PRESENT}

We included 3177 women from 15 institutions in 8 countries within the Oncoplastic Breast Consortium (OPBC) network between January 2010 and December 2013. Of these women, $30 \%$ were treated with OBC (OBC Level I, $n=663$; OBC Level II, $n=297$ ) and the remaining $70 \%$ were treated with conventional breastconserving surgery (BCS). The great majority of patients (92.3\%) had invasive cancer, while the remaining patients had high-grade ductal carcinoma in situ (DCIS). Among patients with invasive cancer, $41 \%$ were luminal B-like, $27 \%$ were human epidermal growth factor receptor 2-positive (HER2+), and 21\% were triple negative.

Patients treated with BCS/OBC Level I had significantly smaller tumors and smaller resection margins compared with patients treated with OBC Level II (pT1: $50 \%$ vs. $37 \%, p=0.002$; proportion of patients with a margin $<1 \mathrm{~mm}: 17 \%$ vs. $6 \%, p<0.001)$. There were significantly more re-excisions due to R1 ('ink on tumor') in the BCS/ OBC Level I group compared with the OBC Level II group ( $11 \%$ vs. $7 \% ; p=0.049)$. At a median follow-up of 74.5 months, there was no difference in local, regional, and distant recurrence-free and overall survival between the two groups. ${ }^{5}$

\section{FUTURE}

Oncoplastic Level II resections increase margin width and decrease the number of re-excisions due to positive margins, but are not associated with lower local recurrence 
rates. The results of this study reinforce the concept that in invasive cancer, margins larger than 'no ink on tumor' do not improve local control.

FUNDING Open access funding provided by Medical University of Vienna.

DISCLOSURES Florian Fitzal has received personal honoraries and educational grants from Pfizer, Novartis, Roche, Astra Zeneca, Springer, Medtronic and Bondimed. Walter P. Weber has received research support from Takeda Pharmaceuticals International via the Swiss Group for Clinical Cancer Research (SAKK), honoraria/consultation from Genomic Health, Inc., USA, and support for conferences and meetings, paid to the University Hospital Basel, from Sandoz, Genomic Health, Medtronic, Novartis Oncology, Pfizer and Eli Lilly. Giacomo Montagna and Angelika Geroldinger have no conflicts of interest to report.

OPEN ACCESS This article is licensed under a Creative Commons Attribution 4.0 International License, which permits use, sharing, adaptation, distribution and reproduction in any medium or format, as long as you give appropriate credit to the original author(s) and the source, provide a link to the Creative Commons licence, and indicate if changes were made. The images or other third party material in this article are included in the article's Creative Commons licence, unless indicated otherwise in a credit line to the material. If material is not included in the article's Creative Commons licence and your intended use is not permitted by statutory regulation or exceeds the permitted use, you will need to obtain permission directly from the copyright holder. To view a copy of this licence, visit http://creativecommons. org/licenses/by/4.0/.

\section{REFERENCES}

1. Clough KB, Ihrai T, Oden S, Kaufman G, Massey E, Nos C. Oncoplastic surgery for breast cancer based on tumour location and a quadrant-per-quadrant atlas. Br J Surg. 2012;99(10): 1389-95.

2. Hoffmann J, Wallwiener D. Classifying breast cancer surgery: a novel, complexity-based system for oncological, oncoplastic and reconstructive procedures, and proof of principle by analysis of 1225 operations in 1166 patients. BMC Cancer. 2009;9:108.

3. Shaitelman SF, Jeruss JS, Pusic AL. Oncoplastic Surgery in the Management of Breast Cancer. J Clin Oncol. 2020;38(20): 2246-53.

4. Weber WP, Morrow M, Boniface J, et al. Knowledge gaps in oncoplastic breast surgery. Lancet Oncol. 2020;21(8):e375-85.

5. Fitzal F, Bolliger M, Dunkler D, et al. Retrospective, multicenter analysis comparing conventional with oncoplastic breast conserving surgery: oncological and surgical outcomes in women with high-risk breast cancer from the OPBC-01/iTOP2 study. Ann Surg Oncol. 2021. https://doi.org/10.1245/10434-021-10809-1.

Publisher's Note Springer Nature remains neutral with regard to jurisdictional claims in published maps and institutional affiliations. 